\title{
Spurious hyperkalaemia and hyponatraemia in a patient with thrombocythaemia
}

\author{
J. B. WHITFIELD \\ From the Department of Biochemistry, Queen Elizabeth Hospital, Birmingham
}

SYNOPSIS Changes in serum potassium and sodium during blood clotting in a patient with thrombocythaemia are described. In such patients falsely high results for potassium and falsely low results for sodium may be obtained.

In 1958 Hartmann, Auditore, and Jackson reported high serum potassium values in cases of thrombocythaemia. They ascribed this to the release of potassium from platelets on clotting, and coined the term 'spurious hyperkalaemia'. Wills and Fraser (1964) reported analogous cases of spurious hyperkalaemia due to breakdown of leucocytes when blood from patients with leukaemia was allowed to stand before separation of the plasma. The object of this paper is to report a case in which there was spurious hyperkalaemia and hyponatraemia in association with thrombocythaemia.

\section{MATERIAL AND METHODS}

A 76-year-old man, A.B., was found on admission to have a serum potassium level of $6.9 \mathrm{mEq}$. per litre. The red cell count was $3.6 \times 10^{6}$ per c.mm., the white cell count 28,000 per c.mm., and the platelets $3.18 \times 10^{6}$ per c.mm. Since this serum potassium result was unexpectedly high, and in view of the findings of Hartmann et al. (1958), the plasma potassium level was determined on a sample of heparinized blood. This was found to be $4.2 \mathrm{mEq}$. per litre and it was concluded that the discrepancy of $2.7 \mathrm{mEq}$. per litre was due to release of potassium from the platelets on clotting. To study the changes in sodium and potassium concentrations during clotting, a sample of blood was taken from A.B. and divided into seven parts: six were allowed to clot in glass tubes at room temperature $\left(24^{\circ} \mathrm{C}\right.$.) and the seventh was prevented from clotting by the use of heparin. Taking the plasma values obtained from the heparinized sample, which was separated within 15 minutes of being taken, as the plasma sodium and potassium in vivo, the increase in potassium and decrease in sodium concentration in the serum with time were observed by separating the sera from the clots at intervals of up to two hours after the blood was taken and estimating the sodium and potassium concentrations with the AutoAnalyzer (Snodgrass, Received for publication 21 March 1966. 
Pfleiderer, Otto, and Hardegg (1959) reported a difference between plasma and serum potassium in seven normal men. They found that the serum potassium exceeded the plasma potassium by between 0.57 and $0.87 \mathrm{mEq}$. per litre. Further experiments on serum and plasma in this laboratory have confirmed a difference between plasma and serum potassium, but have failed to establish any significant difference between plasma and serum sodium.
I should like to express my thanks to Dr. T. P. Whitehead and Dr. W. Westwood for their advice and help.

\section{REFERENCES}

Hartmann, R. C., Auditore, J. V., and Jackson, D. P. (1958). J. clin. Invest., 37, 699.

Pfleiderer, T., Otto, P., and Hardegg, W. (1959). Klin. Wschr., 37, 39. Snodgrass, P. J., Fuwa, K., and Hviid, K. (1962). J. Lab. clin. Med., $60,983$.

Wills, M. R., and Fraser, I. D. (1964). J. clin. Path., 17, 649.

\section{The July 1966 Issue \\ THE JULY 1966 ISSUE CONTAINS THE FOLLOWING PAPERS}

Cultural characters of a newly recognized group of hospital staphylococci M. PATRICIA JEVONS, MADELEINE JOHN, and M. T. PARKER

Some observations on the penetration of antibiotics through mucus in vitro B. A. SAGGERS and DAVID LAWSON

A new disinfectant PHILIP W. Ross

Terminal disinfection of infant feeds K. E. A. HUGHES, E. M. DARMADY, and S. E. DREWETT

Coxsackie group B fatal neonatal myocarditis associated with cardiomegaly $\quad$ R. C. JENNINGS

Studies on placantae and infants from women vaccinated for smallpox during pregnancy $P$. WENTWORTH

Predisposition to thrombosis not reflected by the blood coagulogram B. SOLYMOSS, H. SELYE, and G. GABBIANI

Coagulation studies in massive pulmonary haemorrhage of the newborn J. T. ROBERTS, A. J. DAVIES, and A. L. BLOOM

Serological screening test for infectious mononucleosis using papain-treated sheep erythrocytes L. ROBINSON and $\mathrm{H}$. SMITH

Effect of normal and atheromatous aortic tissue on platelet aggregation in vitro C. R. M. PRENTICE, G. $P$. MCNICOL, and A. S. DOUGLAS

Technique for the evaluation of cold antibodies in cases for operation under hypothermia EUNICE M. BATCHELOR, KATHLEEN E. BOORMAN, P. J. LINCOLN, and R. A. ZEITLIN

Plasma fibrinogen and plasminogen levels in health and in ischaemic heart disease c. M. OGSTON and D. OGSTON

Measurement of arterial and capillary blood oxygen tension J. H. JOHNSTONE
Iron chelation in haematomas at fracture sites $\mathrm{M}$. C. o'SHAUGHNESSY, GILLIAN M. BRUNSTRÖM, and J. FIELDING

Mucoprotein-containing histiocytes (muciphages) in the rectum J. G. AZZOPARDI and D. J. EVANS

Bronchogenic squamous cell carcinoma metastasizing to Bowman's capsule LIVIA ROSs

Possible use of phosphohexose isomerase as a preliminary to exfoliative cytology in screening for cervical carcinoma GRAINGER G. MUIR

Squamous epithelium in the human thyroid gland J. N. HARCOURT-WEBSTER

Prediction of lean body mass from height and weight R. HUME

Factors determining the aggregation of urinary mucoprotein E. G. MCQUEEN and G. B. ENGEL

\section{Technical methods}

Improved method for the automatic determination of serum inorganic phosphate D. S. YOUNG

Estimation of haemoglobin using a Technicon AutoAnalyzer J. H. KEMP

Improved method for direct counting of basophil leucocytes J. R. COOPER and C. N. D. CRUICKSHANK

Modified bistoury for necropsy work W. WALLACE PARK

Modified procedure for pyocine typing J. KOHN

Association of Clinical Pathologists: 76th general meeting

Letter to the Editor

Book reviews

Copies are still available and may be obtained from the PUBLISHING MANAGER, BRITISH MEDICAL ASSOCIATION, TAVISTOCK SQUARE, W.C.1, price 18s. 6D. 